\title{
Etnomatika Pada Permainan Setatak Sebagai Bahan Pembelajaran Bangun Datar (Lingkaran, Persegi dan Persegi Panjang)
}

\author{
${ }^{1}$ Dikdik Iskandar \\ ${ }^{1}$ Pendidikan Matematika, Fakultas Keguruan dan Ilmu Pendidikan, Universitas Muhammadiyah \\ Sukabumi \\ Dikdikiskandar97@gmail.com
}

\begin{abstract}
Abstrak
Pembelajaran matematika merupakan hal yang wajib didapatkan oleh setiap manusia, karena pembelajaran matematika ini sangat penting bagi masa depan manusia. Pembelajaran matematika tidak hanya menyangkut soal rumus maupun teori, tetapi pembelajaran matematika ini sering kita jumpai di kehidupan sehari hari. Salah satu pembelajaran matematika yang dapat kita lakukan melalui permainanpermainan tradisional yang ada di sekitar kita, diantaranya permainan setatak. Melalui permaianan ini diharapkan dapat mengetahui manfaat pembelajaran matematika. Metode yang dilakukan penulis dalam penulisan artikel ini berasal dari sumber berupa pustaka-pustaka, baik berupa buku, artikel maupun jurnal-jurnal yang mempunyai korelasi terhadap pembahasan masalah. Dari permainan setatak tersebut terdapat beberapa konsep matematika yang diberikan salah satunya pembelajaran bangun datar. Konsep tersebut dapat dikaitkan terhadap pembelajaran matematika salah satu dalam pengkajian soal cerita guna memperkenalkan etnomatematika.
\end{abstract}

Kata kunci: etnomatika, pembelajaran matematika, permainan setatak.

\section{PENDAHULUAN}

Rosa \& Orey (2011:35) The prefix ethno is today accepted as a very broad term that refers to the socialcultural context and therefore includes language, jargon, and codes of behavior, myths, and simbols. The derivation of mathema is difficult, but tends to mean to explain, to know, to understand, and to do activities such as ciphering, measuring, classifying, inferring, and modeling. The suffix tics is derived from techne, and has the same root as technique.

Secara bahasa, awalan "ethno" diartikan sebagai sesuatu yang sangat luas yang mengacu pada konteks sosial budaya termasuk bahasa, jargon, kode perilaku, mitos, dan simbol. Kata dasar "mathema" cenderung berarti menjelaskan, mengetahui, memahami, dan melakukan kegiatan seperti pengkodean, mengukur, mengklasifikasi, menyimpulkan, dan pemodelan. Akhiran “tics" berasal dari techne, dan bermakna sama seperti teknik. Jadi etnomatematika memiliki pengertian lebih luas dari hanya sekedar ethno (etnik) maka secara bahasa etnomatematika dapat didefinisikan sebagai antropologi budaya (culture antropologi of mathematics) dari matematika dan pendidikan matematika.

Powel (1997:16) yang menyatakan bahwa "The mathematics which is practiced among identifiable cultural groups such as national-tribe societies, labour groups, children of certain age brackets and professional classes". Matematika yang dipraktekkan diantara kelompok budaya diidentifikasi seperti masyarakat nasional suku, kelompok buruh, 
anak-anak dari kelompok usia tertentu dan kelompok profesional. D’Ambrosio (1999:146) yang menyatakan bahwa "I have using the word ethnomathematics as modes, styles, and techniques (tics) of explanation of understanding, and of coping with the natural and cultural environment (mathema) in distinct cultural systems (ethnos". Dapat kita simpulkan bahwa etnomatematika dapat digunakan sebagai mode, gaya dan teknik (tics) menjelaskan, memahami, dan menghadapi lingkungan alam dan budaya (mathema) dalam system budaya yang berbeda (ethnos).

Shirley dalam Astri Wahyuni dkk (2013: 115) berpandangan bahwa sekarang ini bidang etnomatematika, yaitu matematika yang timbul dan berkembang dalam masyarakat dan sesuai dengan kebudayaan setempat, merupakan pusat proses pembelajaran dan metode pengajaran (Aini et al., 2018). Hal ini membuka potensi pedagogis yang mempertimbangkan pengetahuan para siswa yang diperoleh dari belajar di luar kelas. Budaya adalah suatu cara hidup yang berkembang dan dimiliki Bersama oleh sebuah kelompok orang dan diwariskan dari generasi ke generasi. Budaya dapat digunakan sebagai sarana untuk mempermudah daam proses pembelajaran, salah satunya adalah pembelajaran matematika di sekolah.

Dengan adanya budaya yang ada di sekitar anak-anak, anak-anak dapat diajak untuk memahami aspek-aspek yang ada dalam budaya tersebut. berdasarkan aspek-aspek yang ada, pendidik dapat menerapkan pembelajaran dengan mengembangkan budaya tersebut. Etnomatematika dipersepsikan sebagai lensa untuk memandang dan memahami matematika sebagai produk budaya yang mengacu pada Bahasa masyarakat, tempat, tradisi, konseptual, dan memberikan makna terhadap dunia fisik dan social (Ascher, 1991).

Permainan tradisional merupakan salah satu budaya yang masih berkembang sampai saat ini. Permainan tradisional sering dilakukan oleh anak-anak.
Permainan tersebut meliputi congklak, dakon, basbasan (dam-daman), delikan (petak umpet), gobag sodor, benthik dan masih banyak permainan tradisional yang lainnya. Biasanya, permainan tersebut dilakukan oleh anak-anak di sekolah maupun di lingkungan tempat tinggal mereka. Kegiatan bermain telah menjadi kebiasaan bagi anak-anak yang dilakukan setiap jam istirahat tiba. Sebagian besar anak-anak yang melakukan permainan tersebut dapat memahami aturan permainan.

Statak adalah permainan tradisional anak-anak yang masih berkembang di Pekanbaru dan sekitarnya. Setatak dimainkan anak-anak untuk menghibur diri mengisi waktu luang. Permainan ini dimainkan sebagai hiburan bagi anak anak yang ada di sana serta sebagai tempat menyalurkan kreatvitas anak-anak dengan tidak mengaitkan suatu kepercayaan atau adat istiadat.

Mengenai latar belakang sosial budaya permainan ini, didalam pelaksanaannya dapat kita mainkan oleh siapa saja dan dengan tidak membedabedakan kelas atau suatu kelompok masyarakat. Baik anak orang kaya, anak orang miskin, ataupun anak keturunan bangsawan. Anak anak disini kebanyakan menjadi satu dalam sebuah kelompok bermain. Dalam permainan ini juga masing-masing anak berusaha menjadi lebih kreatif, lebih cekatan, dan lebih mahir dari pada teman bermain yang lainnya. Namun demikian, semua pelaku permainan tersebut nampak patuh pada peraturan permainan yang sudah ditentukan sebelumnya.

Diperkirakan permainan setatak mulai tumbuh dan berkembang di daerah ini sekitar 1930-an. Permainan ini menjadi sangat berkembang sekitar tahun 1950-an. Biasanya pesertanya terdiri dari 2-6 orang yang berusia 6-12 tahun. Permainan ini dimainkan oleh lak-laki dan perempuan. Tetapi pencampuran anak-anak yang sudah agak remaja segan memainkannya, karena dipandang tak pantas lagi meloncat di muka umum. Karena itulah permainan 
estatak tidak pernah dimainkan oleh para remaja dari dulu sampai sekarang.

\section{METODE}

Sumber data yang digunakan dalam tulisan ini berupa pustaka-pustaka, baik berupa buku, artikel maupun jurnal-jurnal yang mempunyai korelasi terhadap pembahasan masalah. Jenis data yang digunakan adalah data sekunder yang bersifat kualitatif maupun kuantitatif.

\section{HASIL DAN PEMBAHASAN}

Permainan tradisional merupakan salah satu budaya yang masih berkembang sampai saat ini. Permainan tradisional sering dilakukan oleh anak-anak. permainan tersebut meliputi congkak, dakon, bas-basan (dam daman), delikan (petak umpet), gobag sodor, benthik, dan masih banyak permainan tradisional yang lainnya. Biasanya permainan tersebut dilakukan oleh anak-anak di sekolah maupun di lingkungan tempat tinggal mereka. Kegiatan bermain telah menjadi kebiasaan bagi anak-anak yang dilakukan setiap jam istirahat tiba. Sebagian besar anak-anak yang melakukan permainan tersebut dapat memahami aturan permainan.

Statak adalah permainan tradisional anak-anak yang masih berkembang di Pekanbaru dan sekitarnya. Setatak dimainkan anak-anak untuk menghibur diri mengisi waktu luang. Permainan ini dimainkan sebagai hiburan bagi anak anak yang ada disana serta sebagai tempat menyalurkan kreativitas anak-anak dengan tidak mengaitkan suatu kepercayaan atau adat istiadat

Mengenai latar belakang sosial budaya permainan ini, didalam pelaksanaannya dapat kita mainkan oleh siapa saja dan dengan tidak membedabedakan kelas atau suatu kelompok masyarakat. Baik anak orang kaya, anak orang miskin, ataupun anak keturunan bangsawan. anak anak disini kebanyakan menjadi satu dalam sebuah kelompok bermain. dalam permainan ini juga masing-masing anak berusaha menjadi lebih kreatif, lebih cekatan, dan lebih mahir dari pada teman bermain yang lainnya. Namun demikian, semua pelaku permainan tersebut nampak patuh pada peraturan permainan yang sudahditentukan sebelumnya.

Diperkirkan, permainan setatak mulai tumbuh dan berkembang di daerah ini sekitar 1930-an. Permainan ini menjadi sangat berkembang sekitar tahun 1950-an. Biasanya pesertanya terdiri dari 2-6 orang yang berusia 6-12 tahun. Permainan ini diamankan oleh laki laki dan perempuan. Tetapi pencampuran anak-anak yang sudah agak remaja segan memainkannya, karena dipandang tak pantas lagi meloncat di muka umum. Karena itulah permainan estatak tidak pernah dimainkan oleh para remaja dari dulu sampai sekarang.

Hal yang diperlukan dalam melakukan hal ini yaitu lapangan tempat bermain, sebelum permainan di mulai anak-anak biasanya bersama-sama menggaris tanah untuk membuat lapangan permainannya. Kemudian ucak (gacuk) digunakan sebagai penikam setatak alat ini biasanya terbuat dari serpihan keramik atau kenteng dan dibuat oleh anak anak itu sendiri. Gacuk ini juga dibuat sedemikian rupa agar dapat terlihat bagus dan tidak membahayakan penggunanya serta tidak melukai pemain lainnya. Ucak ini dibuat sebesar 22/7 x $6 \mathrm{~cm}$. permainan ini juga dimainkan oleh dua sampai lima orang secara bergantian. Alat permainan setatak ada terdiri dari dua jenis yaitu:

1. Arena Bermain

Arena bermain berupa pola geometris yang digambar di lapangan atau tanah.

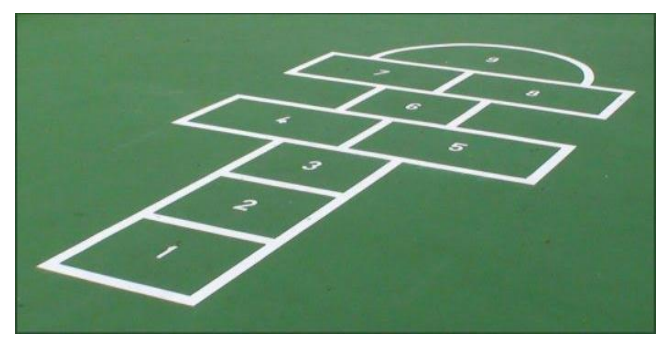

Gambar Permainan Setatak 1 
Gacuk atau ucak adalah benda pipih berbentuk bulat. Ucak ini bisa dibuat dari plastik tebal, pecahan piring yang di tumpulkan tepinya agar tidak membahayakan.

Urutan permainan setatak adalah sebagai berikut:

1. Para pemain melewati arena permainan setatak dengan cara berjingkat dan melompat menggunakan satu kaki.

2. Tangan dan kaki tidak boleh menyentuh arena permainan pada permainan setatak.

3. Petak yang memiliki ucak, tidak boleh diinjak oleh kita kecuali ucak itu milik kita tapi harus dilompati dengan satu kaki.

4. Setiap selesai 1 ronde, pemain mengambil bintang.

5. Pengambilan bintang dilakukan dengan cara berdiri membelakangi arena dibawah petak satu, lalu melempar ucak ke belakang, petak tempat jatuh ucak menjadi milik dengan menandai tanda bintang.

6. Petak yang telah sudah ada bintangnya, boleh diinjak dengan dua kaki oleh pemiliknya, tapi tidak boleh diinjak oleh lawan.

Secara umum arena bermain seatak menyerupai persegi, persegi panjang dll. Dimana persegi dan persegi panjang ini merupakan bangun datar yang di bahas dalam mata pelajaran matematika. Dari pembahasan tersebut juga menunjukan bahwa terdapat konsep-konsep matematika dari permainan setatak, khususnya pada arena bermain nya.

Bentuk bentuk bangun datar pada arena permainan setatak adalah sebagai berikut

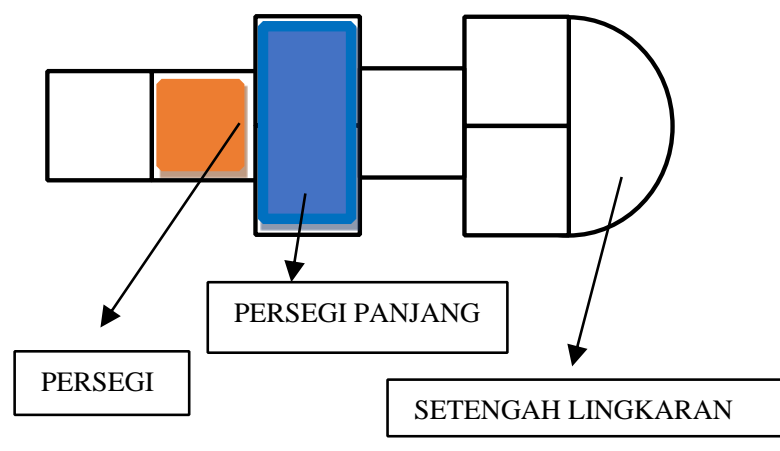

Gambar Permainan Setatak 2

Dengan demikian terdapat konsep matematika pada permaianan setatak. Permainan setatak merupakan permainan tradisional yang dapat melatih kemampuan siswa untuk mengenal bentuk bangun datar. Selain itu penguasaan konsep geometri pada permainan setatak adalah kemampuan anak dalam membedakan antara persegi, persegi panjang dan setengah lingkaran.

\section{PENUTUP}

\section{Simpulan}

Berdasarkan pembahasan yang telah dipaparkan, dapat disimpulkan bahwa etnomatematika sangat cocok dijadikan sebagai bahan pembelajaran matematika kepada siswa karena pada saat itu siswa dapat melihat dan merasakan bagaimana hubungan dan kaitan antara berbagai macam hal. Hal ini dapat membantu siswa untuk mengaitkan antara pelajaran matematika di sekolah dengan matematika yang ada dikehidupan sehari-hari sehingga dapat mempermudah siswa mengerti materi yang diajarkan dan membuat kemampuan matematika siswa meningkat dalam menyelesaikan soal penalaran dan pemecahan masalah. Hasil pembelajaran pun lebih bermakna karena hasil pembelajaran bisa dirasakan dalam kehidupan seharihari siswa.

Etnomatematika juga telah tumbuh dan berkembang pada permainan setatak. Terdapat konsep matematika yang terkandung dalam permainan setatak. Konsep tersebut yaitu konsep geometri bangun datar. Etnomatematika permainan setatak dapat 
diimplementasikan dalam pembelajaran di luar kelas. Adapun pembelajarannya yaitu pembelajaran geometri bangun datar dengan memasukkan etnomatematika ke dalam pembelajaran memberikan alternatif bagi pendidik dalam membelajarkan siswa mengenai konsep matematika. Selain itu juga dapat meningkatkan motivasi belajar matematika siswa, yang akhirnya berdampak pada pembelajaran bermakna.

\section{Saran}

Pada tulisan ini, penulis memberi saran, diantaranya adalah meninjau manfaat yang dapat memotivasi para siswa, guru alangkah baiknya memperkenalkan etnomatika ini pada pembelajaran matematika formal, sebagai langkah awal mengajarkan konsep matematika berbasis budaya kepada siswa. Hasil tulisan ini dapat dijadikan ide alternatif proses pembelajaran matematika yang lebih inovatif dan kontekstual untuk sistem pendidikan di Indonesia. Penulisan ini belum terlalu banyak membahas tentang etnomatematika yang ada serta belum terlalu mendalam artinya masih perlu dikembangkan lagi, sehingga pembaca bisa ikut melengkapi bagian yang kurang menddalam untuk dijadikan penulisan lanjutan.

\section{DAFTAR PUSTAKA}

D’ Ambrosio, U. 1985. Ethnomathematics and its Place in the History and Pedagogy of Mathematics. For the Learning of Mathematics, 5(1), 44-47.

D' Ambrosio, U. 1999. Literacy, Matheracy, and Technoracy: A Trivium for Today. Mathematics Thinking and Learning, 1(2), 131-153.

Hanafi, Miftah Rizqi, dkk. 2013. Borobudur Smart Math, Aplikasi Media Pembelajaran Geometri Berbasis Ethnomatematika. http://nec.rema.upi.edu/wpcontent/uploads/sit es/27/2013/11/16.-BOROBUDUR-SMARTMATH-APLIKASI-MEDIAPEMBELAJARANGEOMETRIBERBASISE THNOMATEMATIKA.pdf. [diakses: 11/12/2014]

Aini, E. P., Masykur, R., \& Komarudin, K. (2018). Handout Matematika berbantuan Etnomatematika Berbasis Budaya Lokal. Desimal: Jurnal Matematika, 1(1), 73-79. https://doi.org/10.24042/djm.v1i1.1950
Rahman, Elmust. 2008. Atlah kebudayaan melayu riau tahap II.

Kharisna, Nila. 2010. "permainan rakyat". https://permainanrakyat.blogspot.com. 